\title{
Report of an experience: self-study to foster self- regulated learning for International Dental Degree Program (IDDP) students in Canada
}

\author{
Renata Grazziotin-Soares*; Peter Doig**; Diego Machado Ardenghi *** \\ * DDS, MSc, PhD, College of Dentistry, University of \\ Saskatchewan, Canada \\ ** DMD, Dip Management, College of Dentistry, University \\ of Saskatchewan, Canada \\ *** DDS, MA (Educ), MSc, Dip. Pros, FRCD (C), College of \\ Dentistry, University of Saskatchewan, Canada
}

Received: 08/22/2020. Approved: 02/02/2021.

\begin{abstract}
This article aimed to briefly report a self-study methodology experience performed in the International Dental Degree Program (IDDP) in a University in Canada. This approach fostered students`self-regulated learning. Due to Covid-19 pandemic the on-site dentistry school classes were discontinued. Students from the IDDP were allowed to go to on-site only to perform pre-clinical activities (supervised by one faculty member at a time). As the 2020 class of the IDDP program was small (2 students), the director of the IDDP Program and faculty members considered that self-study would be an appropriate idea. We noticed that students were successful in self-regulating their learning. Some of the examples for that were: students used note-taking sheets, monitored their comprehension of class lecture material, asked questions etc. The experience with IDDP students showed that the self-study opportunity was a favorable learning environment for the teaching of preclinical disciplines.
\end{abstract}

Descriptors: Education, Dental; Students, Dental; Evidence-Based Dentistry.

\section{INTRODUCTION}

The International Dental Degree Program (IDDP) in our university (https://programs. usask.ca/dentistry/iddp/index.php) is a program for students who have already earned a dental degree from an institution in another country that is not recognized by the Commission of Dental Accreditation of Canada (www.cda-adc.ca). This program allows students to complete their degree in a shorter time than the full four-year Doctor of Dental Medicine (D.M.D.) program. In place of the first two years of the full four-year program, the 
student attends a spring/summer session of preclinical disciplines, aiming to review the essential dentistry skills. From there, students join third year dentistry students and complete the regular program (www.admissions.usask.ca). After completing the IDDP, the student becomes eligible to sit the National Dental Examining Board of Canada (NDEB) examinations, which are required for licensure in Canada ${ }^{1}$.

Self-study means that the majority of student learning time is spent independently working outside the classroom. Students take an active role in setting goals, deciding how to achieve them, and planning individual study time $^{2}$. The conceptualization of self-study includes the following: it should be self-initiated and focused; improvement-aimed; interactive; and it should include multiple, mainly qualitative, methods ${ }^{3}$. Under this autonomous learning environment, students`self-monitoring and organization become of paramount importance, demanded a self-regulated learning ability $^{4,5}$. The degree to which students are metacognitively, motivationally and behaviourally active in steering their own learning is described as self-regulated learning ${ }^{6}$.

\section{REPORT OF AN EXPERIENCE}

The COVID-19 situation made some changes at the University of Saskatchewan teaching approach. The on-site dentistry school classes were discontinued in March 2020. In July 2020, with the dental building still closed, we began a new class (with 2 students) of the International Dental Degree Program (IDDP). These students needed to receive all pre-clinical dental instruction before beginning the regular $3^{\text {rd }}$ year in August. The University rules are to restrict the flow of people inside the buildings; thus, no dental classes are happening, and the IDDP students are allowed to go to on-site only to perform pre-clinical activities (supervised by one faculty member at a time). Therefore, all theoretical instruction should be delivered remotely. Remote lectures sometimes are passive and do not give the chance for students to regulate their learning and to become active coproducers of learning.

The director of the IDDP Program and faculty members considered that self-study would be an appropriate idea for this small class of international students. Self-study aimed to foster students' capacity to self-regulate their learning. As mentioned above, the self-regulated learning should involve three aspects of academic learning: 1) self-regulation of behavior (to be able to control the time, study environment, the need for help from instructors and other peers etc.); 2) self-regulation of motivation (controlling efficacy, goal orientation, and emotions e.g., reducing anxiety); and 3) cognitive self-regulation (using strategies, such as: taking notes, drawing concept-maps, flowcharts etc.). Self-regulated learning is not a personality 'style' or trait that the individual has no control over. On the contrary, students can control their behavior, motivation, affect and cognition aiming to improve their academic learning and performance ${ }^{7}$. With that in mind, faculty made all theoretical material (text, images, videos, quiz) from pre-clinical disciplines available online (Blackboard Inc., US) and students should learn from that. In addition to that, references (books and articles) were suggested as complementary material.

We noticed that students were successful in self-regulating their learning (with some differences over time and across disciplines). They brought their note-taking sheets to guide the pre-clinical procedures, they mentally reviewed steps of tasks - outlining and integrating the course material - and they monitored their comprehension of class lecture material not being afraid of asking questions. 
Students accepted their responsibility on learning and realized that they have the potential to control their own learning ${ }^{8}$.

Our students were successful, perhaps because their level of professionalism, basicknowledge on the field and motivation (already graduated dentists from a foreign school wanting to get a Canada dentistry license). Faculty can help self-regulated learning by providing opportunity for students to choose how they go about studying and learning, and how is the quality of cognitive effort they put into learning.

\section{CONCLUSIONS}

Considering our small group of previous dentistry educated professionals; the experience with IDDP students showed that the self-study opportunity was a favorable learning environment for the teaching of pre-clinical disciplines. Similar approaches might be successful for other students` profiles such as: preclinical phase of graduate diploma/Lato-sensu programs, and technical-dentistry-oriented phase of Stricto-sensu (MSc, PhD) programs.

\section{RESUMO}

Relato de experiência: estudo autônomo para encorajar o aprendizado autorregulado dos estudantes do Programa de Graduação Internacional de Odontologia (IDDP) no Canadá

Este artigo objetivou descrever brevemente uma experiência com a metodologia de estudo autônomo realizada no Programa de Graduação Internacional de Odontologia (IDDP) em uma Universidade no Canadá. Esta abordagem encorajou o aprendizado autorregulado dos estudantes. Devido à pandemia COVID-19 as aulas "on-site" da faculdade de odontologia foram descontinuadas. Os estudantes do programa IDDP eram permitidos frequentar o prédio da faculdade somente para realizar as atividades pré-clínicas (e eram supervisionados por apenas um professor de cada vez). Como a turma de 2020 do programa IDDP era pequena ( 2 alunos), o diretor do programa e os professores consideraram que o estudo autônomo seria uma ideia apropriada. Percebeu-se que os estudantes tiveram sucesso em autorregular o aprendizado. Como por exemplo: usaram suas anotações, monitoraram a compreensão do material teórico disponibilizado, fizeram perguntas etc. A experiência com os estudantes do programa IDDP mostrou que a oportunidade de estudo autônomo se caracterizou como um ambiente favorável para os professores usarem nas disciplinas pré-clínicas.

Descritores: Educação em Odontologia, Estudantes de Odontologia, Odontologia Baseada em Evidências.

\section{REFERENCES}

1. Boorberg NB, Schönwetter DJ, Swain VL. Advanced placement, qualifying, and degree completion programs for internationally trained dentists in Canada and the United States: an overview. J Dent Educ. 2009;73(3):399-415.

2. Barbosa J, Silva A, Ferreira MA, Severo M. The impact of students and curriculum on self-study during clinical training in medical school: a multilevel approach. BMC Med Educ. 2017;17:9.

3. Mishler E. Validation in inquiry-guided research: The role of exemplars in narrative studies. Harvard Educational Review. 1990;60(4), 415-42.

4. LaBoskey VK. The methodology of selfstudy and its theoretical underpinnings. Chapter 21. In: Loughran JJ, Hamilton ML, LaBoskey VK, Russell T. International Handbook of Self-Study of Teaching and Teacher Education Practices. Springer International Handbooks of Education book series (SIHE, volume 12), 2004.

5. Lan M, Hou X, Qi X, Mattheos N. Selfregulated learning strategies in world's first 
MOOC in implant dentistry. Eur J Dent Educ. 2019;23(3):278-85.

6. Zimmerman M-P. Construct validation of a strategy model of student self-regulated learning. J Educ Psychol. 1988;80(3):284.
7. Pintrich PR. Understanding self-regulated learning. New Directions for Teaching and Learning (NDTL) 1995; 63:3-12.

8. Bowman M. The transition to self-regulated learning for first-year dental students: threshold concepts. Eur J Dent Educ. 2017;21(3):142-50.

\section{Correspondence to:}

Renata Grazziotin-Soares

e-mail: renata.grazziotin@usask.ca 105 Wiggins Rd, College of Dentistry University of Saskatchewan

SK, Canada, S7N 5E4 